\title{
8 Rape law and coercive circumstances
}

\author{
Helena Jokila and Johanna Niemi
}

\section{Introduction}

Rape law has undergone several changes since the second-wave feminist movement placed such legislation on the agenda in the 1970s (Brownmiller, 1974/ 1993; Estrich, 1987). One central debate has been whether lack of consent or use of force should be considered the basic element of rape (MacKinnon, 1996, 2006; McGlynn \& Munro, 2010). Broadly speaking, the European continental countries have historically relied on (and still rely on) use of force in their definitions of rape, while the Anglo-Saxon countries use lack of consent as the central element of rape (European Court of Human Rights [ECtHR] M. C. v Bulgaria, 2003, pp. 156-162; Munro, 2010). Alongside these two legislative strategies, the International Criminal Tribunals for Rwanda and for the Former Yugoslavia (ICTR and ICTY, respectively) have convicted as rape any sex crimes committed under coercive circumstances, under which no consent can be valid. Recent international documents and case law have again emphasised lack of consent as the essential element of rape, and a similar trend has occurred in the Nordic countries.

We argue in this chapter that the differences between the two main legal definitions of rape are more of a technical nature than about the underlying understanding of rape as a type of wrongdoing. We argue that, despite their differences, the two strategies of rape law at a deeper level share the same ontological and epistemological basis and offer insufficient responses to rape under coercive circumstances. At the ontological level, both definitions focus on a certain criminal act and exclude context. In this chapter, we focus on the coercive circumstances of rape and how the courts take such circumstances into account.

Epistemologically, evidence in the courts is connected to physical signs of violation, external observation by witnesses and, increasingly, expert testimony of trauma. The purpose of evidence is to show that the individualised act happened, not to provide evidence of the surrounding circumstances.

Historically, the notion of the context of rape has broadened to show that the victim had behaved in a way that demonstrated consent or lack of resistance by drinking, flirting or her manner of dressing (O'Donovan, 1997, p. 53). In this 
chapter, we look at the context of rape from another perspective. We use the concept of coercive circumstances (taken up by the ICTR and ICTY) and look at the case law of the ECtHR and the Finnish courts to see how they have noted elements of coercive circumstances. First, we briefly present national legislative discourses. While we focus on Finland, we also refer to developments in other Nordic countries and in Canada.

The concept of coercive conditions that the ICTR and ICTY used concerned fairly extreme circumstances. Munro (2010) has argued that the coercivecircumstances element is problematic in national contexts of rape (as opposed to international or armed conflicts). She argues that there is a qualitative difference between rapes in these circumstances. During conflicts, rape is committed in the context of other wrongful acts; the perpetrator and victim do not know each other and belong to antagonistic ethnic or social groups. In peacetime, many rapes are committed between people who are close to each other or know each other, rapes are not always accompanied by other forms of physical violence and threats, and the power relations at play are more complex (Munro, 2010 , p. 24). In addition, replacing consent with the idea of coercive circumstances would undermine women's sexual autonomy (Munro, 2010, p. 26).

In this chapter we investigate what the consideration of coercive circumstances would mean in the adjudication of rape under normal, peacetime circumstances. Our empirical data are drawn from Finnish courts. We focus on cases of rape in intimate partnerships and among youth - both of which illuminate problems in the application of rape law - and analyse what kinds of coercive circumstances are present in these types of rape and how the courts have addressed these circumstances.

\section{Theory, method, and data}

Theoretically, law is a social construction, made in legislative processes and legal practices. Relying on constructionist theory, we argue that facts are also socially constructed during these processes (Berger \& Luckmann, 1966; Burr, 1995). Thus, the courts construct the facts of a given case, and criminal law guides crime-investigation processes and interpretations (Bennet \& Feldman, 1984; Niemi-Kiesiläinen, Honkatukia \& Ruuskanen, 2007).

In criminal-law doctrine, sexual self-determination is the foremost value protected by criminal law on sex crimes. Self-determination is a central aspect of personal autonomy, which is the central tenet of the construction of legal personhood. In legal doctrine, a 'person' is usually understood to be a unified, pre-existing and stable entity who is morally immune to and isolated from the influence of other people. We instead adhere to critical analysis of the legal person and autonomy, according to which personality and autonomy develop during social interactions with other people. Interaction makes the capacity to self-determine possible. We draw on the relational concept of autonomy proposed by several feminist legal theorists (Davies, 2001; Fineman, 2004; Naffine, 2011). 
The relational understanding of autonomy is linked to trust (Lacey, 1998, pp. 62-68; Nedelsky, 1989, p. 11), which can be defined in different ways. Drawing on Govier (1993) and Brothers (1982), we understand trust to be an affective entity and an individual and social experience - as a feeling of being safe with other people. In psychology and feminist philosophy, trust in other people and self-trust are thought of as supporting people's experiences of themselves as autonomous people (Brothers, 1982) and as the precondition for acting as moral people (Govier, 1993).

Psychological studies indicate that a breach of trust in a sexual relationship has unique consequences for victims. A person's self-trust and self-respect can collapse (Brothers, 1982) and can severely shake someone's belief system about the world. The betrayal of trust can destroy the feeling of being safe in the intimate private sphere and of having control over one's life. Victims of sexual violence in intimate relationships typically suffer from the psychological consequences of the crime longer than victims of stranger rape do (Gidycz \& Koss, 1991, p. 279; Katz, 1991, pp. 264-265; Näre, 2000).

In our reading of case law, we are interested in trust: What aspects of the context indicate that a level of trust has existed between the victim and the perpetrator? Do the courts address issues of trust in their decisions?

Today the debates about the elements of rape are international or transnational; we thus refer to discussions in other Nordic countries as the nearest reference points for Finnish legislative processes. Canadian rape law has gone the furthest in requiring affirmative consent for sexual intercourse to proceed. Because most of the pressure to introduce laws that criminalise non-consensual sex has come from international law, we also look at central international documents and cases. Our empirical data consist of published Finnish court decisions on rape (identified through Finlex and Edilex) from 2000 until 2018. In addition, the data include all 98 cases from the Finnish courts of appeal in 1999-2002. From this sample, originally collected by Jokila (2010) for her doctoral thesis, we have analysed cases of intimate partner rape and rape among young people between 16 and 19 years old.

\section{Legal developments}

\section{National laws: from use of force towards lack of consent}

Traditionally, the Nordic countries have relied on a model in which the basic element of rape is use of force or threat of force. This basic definition has been complemented by definitions of rape or sexual abuse that criminalise abuse of a person who is unable to consent or resist because of unconsciousness, illness, disability or similar conditions. Especially after 2004, debates about rape-law reform have shifted towards the lack-of-consent model.

Swedish law included a distinction between rape with the use of force and the sexual abuse of a person who was unable to express resistance until 2018. Between these two sex crimes was an abyss that was debated while several 
cases - referred to by place names such as Jordbro, Rissne, Tumba, Södertälje and Stureplan - were processed through the courts (see Nilsson's chapter in this volume). The facts in these cases had similarities: one victim, usually a young woman, who was intoxicated but not passed out; several men; little to no physical violence; and no evidence of explicit threats and resistance in either words or actions. In some of the cases, the defendants were convicted of rape, while in others the courts dismissed the charges. The central problem was that the victim had not passed out (which would have qualified as sexual abuse), nor was there evidence to show use of force or resistance by the victim (which would have qualified as rape). These cases then fed into a heated debate about the construction of rape (Asp, 2010; Leijonhufvud, 2008). In 2018, the law was changed, and intercourse or a comparable sexual act with someone who does not participate voluntarily is now defined as rape (Brottsbalk 6:1; as amended by law, 2018:618).

Icelandic law has evolved to include both force and lack of consent (Iceland Review, 2018). In Norway, rape is defined as use of force, but the provision of rape with grave negligence mitigates this position, even if this provision is very rarely used. Lack of consent has also been discussed in Norway. Canadian law, which emphasises the victim's consent, requires affirmative consent for sexual intercourse to proceed. The legislation specifically mentions the abuse of trust as an element of rape. Someone who is protected by the criminal provision is constructed as a legal subject who actively and affirmatively utters his or her consent (or non-consent) with words or deeds. Canadian law requires that a person take 'reasonable steps' to find out whether or not a partner is consenting. The use of the defence of 'mistaken belief' regarding the partner's consent is restricted (Gotell, 2010, p. 212). The Canadian model has been called the 'communicative model' of sexuality (Boyle, 1984; Pineau, 1996; critically, Halley, 2016).

Consent is not and has never been a part of the legal definition in Finland. The relevant Finnish legislation defines rape as a violent coercion to engage in sexual intercourse:

A person who forces another into sexual intercourse by the use or threat of violence directed against the person shall be sentenced for rape to imprisonment for at least one year and at most six years. ${ }^{1}$

(Criminal Code [CC] 20:1.1/1999)

Besides the use of force, a rape can be committed by taking advantage of another person's state of unconsciousness, illness, fear or helplessness, all of which make this person incapable of formulating or expressing his or her will to engage in sexual intercourse. ${ }^{2}$ According to the law:

Also a person who, by taking advantage of the fact that another person, due to unconsciousness, illness, disability, state of fear or other state of helplessness, is unable to defend himself or herself or to formulate or 
express his or her will, has sexual intercourse with him or her, shall be sentenced for rape.

(CC 20:1.2/2014/509)

This paragraph was a reformulation of an outdated crime of sexual abuse of an 'unconscious woman'. As a remnant of that previous law, the law still requires the incapability of expressing resistance, but the widening of the scope of vulnerable states brings the law closer to considering coercive circumstances. In addition, the law also includes a less serious form of rape, which can be committed by a less serious threat of force, abuse of a situation of helplessness, or other kind of threat. In such situations, the punishment is meted out on a lower scale:

If the rape, taking into consideration the pettiness of the threat or the other circumstances connected with the offence, is less serious when considered as a whole than the acts referred to in subsections 1 or 2 , the offender shall be sentenced to imprisonment for at least four months and at most four years. A person who forces another into sexual intercourse through other than the threat referred to in subparagraph 1 shall be sentenced in a similar manner. What is provided above in this subparagraph does not apply if violence has been used in the rape.

(CC 20:1.3/2014/509)

The definition of rape includes intercourse. Other sexual acts using force or the abuse of helplessness and similar states constitute the crime of coercion to engage in a sexual act (CC 20:4). The sexual abuse of people in dependent situations is also a crime (CC 20:5). Sex with someone who is 15 years old or younger is considered child sexual abuse (CC 20:6), which we do not discuss in this chapter.

When Finnish rape law was reviewed in 2013, the government discussed the possibility of changing the basic element of rape to sexual non-consent (Ministry of Justice, 2012; RP 216/2013). According to the Finnish government, those countries where a lack of consent is an essential element of rape also have additional evidential rules concerning valid consent. Such evidentiary rules define the circumstances under which adequate consent can be given. The government concluded that such evidentiary rules are not in line with the theoretical doctrines of evidence, based on the free evaluation of evidence. According to the government, the idea that sexual partners would take active steps to determine whether their partners had consented to sex was unnatural (or 'otherworldly', according to RP 216/2013, 37).

Notwithstanding the legal definition, the core problem in the Finnish courts is whether the complainant has consented to a sexual act (Ylikulju, 2017). The Supreme Court (KKO, from the Finnish Korkein Oikeus) has interpreted the elements of force, fear and helplessness:

Because A had said no to the [defendant] ..., the groping and pushing to the bedroom as well as the sitting on top of A, as described in the 
indictment, fulfil the element of violence. Due to the violence and fear and helplessness caused by it, A had been forced to [have] intercourse.

(KKO:2013:96, 46)

According to the Supreme Court, the complainant was proved to have tried to push the defendant away before the rape and that she had forbidden the defendant to continue. The defendant had admitted that he had heard the complainant's refusal. The Supreme Court considered the question of consent:

The Supreme Court states as a point of departure that one cannot derive a consent to [have] intercourse solely on the basis of ending physical or even verbal resistance after having first denied it. The intent or criminal liability is not avoided just because one assumes that the other has changed her mind if the change of mind has not been verbally or otherwise clearly expressed.

(KKO:2013:96, 48)

While the Supreme Court does not explicitly discuss trust in this case, the situation had evolved such that ' $\mathrm{A}$ ' - who knew ' $\mathrm{K}$ ' as an employer of a friend and wished to be hired at K's bar - had invited $\mathrm{K}$ to her apartment. These circumstances indicated some degree of trust in K. The case shows how the interpretation of the use-of-force construction has come close to the lack-of-consent construction, as required by international law instruments. The judgement does not include an explicit reference to the ECtHR decision in M. C. v Bulgaria (2003) nor to the Istanbul Convention, ${ }^{3}$ but the interpretation that use of force actually means lack of consent provides reason to assume that the Supreme Court is aware of the case and the Convention.

\section{International law: from coercive circumstances to consent}

Rape arrived on the agenda of international law under cruel circumstances. Both the ICTR and the ICTY had to consider the elements of rape. The ICTR in Akayesu (1998) and the ICTY in Kunarac (2002) held that the circumstances of the cases were coercive and that consent was therefore irrelevant. ${ }^{4}$ Rape was defined in international law for the first time in the Akayesu case (Munro, 2010); soon after, the statute of the International Criminal Court recognised rape as a war crime and as a crime against humanity (art. 4[c] and 7[1]g; Cole, 2010; Walby et al., 2015, pp. 115-118).

The coercive-circumstances formulation highlights, among other things, the power relationship between parties (MacKinnon, 2006, p. 941). In these cases, the power imbalance was extreme, but the cases raise the question of what kind of coercive circumstances would generally make consent irrelevant. MacKinnon (2006, p. 951) criticised the tribunals for binding the coercive circumstances too closely with the lack-of-consent definition of rape. The use-of-force construction of rape in the Akayesu and Kunarac cases would not solve the issue, because in these cases, the rapes had not been preceded by immediate force or threat. 
Rape remained on the international-law agenda after the Akayesu case, but with an emphasis on lack of consent (UNDAW, 2010, p. 26). The ECtHR stated in M. C. $v$ Bulgaria (2003) that rape should be defined as a crime committed against one's consent. After a review of the definitions of rape in the Council of Europe member states, the ECtHR stated that most continental European definitions of rape are based on violence or threat of violence, whereas in common law, rape is usually constructed as lack of consent (M. C. $v$ Bulgaria, pp. 156-162). The ECtHR ruled that the central question of rape is whether the complainant has consented to engage in sexual activity, and that laws should be interpreted accordingly.

The suitability of the lack-of-consent approach in M. C. v Bulgaria can be questioned. The complainant in the case, a 14-year-old girl, was just above the age of consent, which in Bulgaria was 14 years at the time. She was in the company of three 20- to 21-year-old men in a lonely place when the alleged rape took place. No evidence was found of explicit violence, nor of resistance. The police and the prosecutor closed the case. The ECtHR referred to the coercive circumstances but did not deliberate on them:

The prosecutors forwent the possibility of proving the perpetrators' mens rea by assessing all the surrounding circumstances, such as evidence that they had deliberately misled the applicant in order to take her to a deserted area, thus creating an environment of coercion, and also by judging the credibility of the versions of the facts proposed by the three men and witnesses called by them.

(ECtHR M. C. v Bulgaria, p. 180; emphasis added)

The ECtHR has also examined other cases of the rape of young women in which the court could have considered the legal relevance of the circumstances more broadly (X\& Yv the Netherlands, 1985; Aydin v Turkey, 1997; Maslova \& Nalbandov v Russia, 2008, p. 91; I. G. v Moldova, 2012). In M. C. v Bulgaria, the legal analysis and conclusions were focussed on the interpretation of the use-of-force element in Bulgarian law to include lack of consent. Thus, the crucial moment to develop an interpretation of coercive circumstances was lost. Subsequent analyses of the case have not paid sufficient attention to the coercive circumstances the court mentioned but emphasise consent as the element of rape.

With the judgement of $M$. C. v Bulgaria, the lack of sexual consent became the core element of European rape laws. The European Convention on preventing and combating violence against women and domestic violence (Istanbul Convention 2011) confirms this notion in article 36 , which says that the parties to the Convention must take necessary legislative or other measures to ensure that engaging in non-consensual penetrative or other acts of sexual nature will be criminalised. In addition, the Committee on the Elimination of Discrimination against Women (the CEDAW Committee), in its concluding observations on various country reports, urged the states to set lack of consent as the core element of rape. ${ }^{5}$ As we discuss in the following section, both the lack-of-consent and use-of-force constructions define the context of rape narrowly - in our opinion too narrowly. 


\section{Consent versus force - a false controversy?}

\section{Act-oriented criminal law}

The protected good or interest of rape law is usually defined as sexual selfdetermination. In law drafting and case law, the basic tenets of self-determination are seldom explicated. Self-determination (or 'individual autonomy') is the liberal conception of free sexual choice based on rational decision-making and the underlying mind-body distinction (Lacey, 1998). Both lack of consent and use of force are connected to the concept of autonomy, as feminist researchers have pointed out (Lacey, 1998). In the lack-of-consent construction, the focus is on the expression of opinion by a victim, thus emphasising a complainant's response to actions (earlier conceptualised as seduction) of a perpetrator (MacKinnon, 2016). In the use-of-force construction, the focus is on the denial of the will of the victim. Both constructions focus on the complainant's expression of determination (or the impossibility of expressing one) and exclude the context.

In criminal law, the ontology of a crime is act-oriented. The concrete acts must correspond to the elements as defined in criminal law according to the nullum crimen sine lege or legality principle, that all crimes must be prescribed in law. The level of concretisation of the elements varies. While definitions of crimes against property and the person are narrow in both time and space, in the definitions of economic and environmental crimes, the actions, causality and violations are defined abstractly, and the time span may be long. In the definition of a criminal act, the relevant context is constructed and to some degree contingent (Kelman, 1981; Lacey, Wells \& Quick, 2003; Smart, 1991). In addition to the concrete and objective elements of crime, the criminal responsibility requires a subjective element, usually intent (mens rea), which often is induced from the concrete actions (evidence of facts).

The evidential considerations seem to be similar, notwithstanding the definition of rape. In legal practice, rape is usually established evidentially by virtue of physical signs (physical marks and injuries) as a result of violence and resistance (Jokila, 2010). A complainant's state of mind and behaviour after an alleged rape has occurred are typically used as supporting evidence for the prosecutor's case.

Andersson (2004) concluded in her empirical study that the victims were not thought of as legal actors, except in response to the advances by the perpetrator. According to Jokila's study (2010), the defendants often argued that the complainant had consented. The reporting of facts by the defendants and their lawyers during pre-trial investigations and in written pleadings in that study demonstrated discriminating attitudes towards women and prejudice about male and female sexuality. Pejorative attitudes by the defence have been a widespread problem in criminal justice, regardless of whether the use-of-violence or lack-of-consent models are used (Adler, 1987; Estrich, 1987; Lees, 1996). In two Finnish studies, such prejudicial language was not observed in the verdicts (Jokila, 2010; Ylikulju, 


\section{Helena Jokila and Johanna Niemi}

2017), but the language of the defendants and their lawyers reflected prejudice about the victim, such as interpreting paralysing fear as voluntariness, sexual foreplay and tacit consent (Jokila, 2010). ${ }^{6}$

\section{Rape in intimate relationships}

Historically, rape in marriage was not a crime before the mid-20th century (Burgess-Jackson, 1996; Kotanen's chapter in this volume). Rape in marriage was criminalised in Sweden in 1965, in Canada in 1983, in the UK in the early 1990s (ECtHR, R. C. v UK, 1995) and in Finland in 1994. Already in 1990, Russell found that rape in marriage was more common than previously assumed (Russell, 1990). Intimate partnerships take many forms today, as cohabitation is commonplace. In court cases it is not always clear what the status of a relationship is; on-and-off relationships are not uncommon.

In the Finnish appeal courts in 1999-2002, 18\% of rapes were found to have taken place in intimate partnerships (Jokila, 2010, p. 160). Typically, violence in these cases had been physical, psychological and sexual, repeated and continued over long periods of time. The acts included in the indictment were only a snapshot of long-lasting violence that in some cases continued after the investigation and prosecution had commenced. In these cases, the defendants were usually convicted (Jokila, 2010, p. 171), but in some cases, the type of relationship alleviated the sentence. In some cases, the court dismissed the charges with some of several rapes, and in others the conviction was of rape of a lesser grade (CC 20:1.3).

The courts were willing to stretch the context in these cases, but they obviously had to struggle with the elements of rape. When the victim had not resisted, the courts were sometimes willing to take previous violence into account:

The victim had not dared to resist the defendant because she feared that resistance would lead to violence as had happened before. According to the victim the defendant had not threatened her verbally.

(District Court, 11)

The court discussed how the capacity to self-determination was broken and how this lack could affect the ability of the victim to provide a coherent testimony:

Imprecision (in testimony) can be explained by the nature of crimes against sexual self-determination. An indecent crime takes place by breaking the will of the victim and it always has an effect on the state of mind of the victim.

(District Court, 11)

The defendant was convicted of lesser grade rape (CC 20:1.3). In another case, in which violence preceding the actual rape had also occurred, the defendant was convicted of rape. According to the complainant's appeal in that case: 
The defendant has threatened and assaulted her physically for many years. The complainant has been traumatized, and she is so afraid of her husband, that she doesn't dare to resist his wishes and orders. The complainant has told in the court, that if she somehow resists the defendant, the defendant usually begins to threaten her life. (The complainant's appeal to the Court of Appeal, Court of Appeal 64.)

In this and similar cases, the courts encountered problems in understanding why the victim had let the estranged spouse into the apartment in the first place. The victims had tried to use different strategies to avoid violence and disturbance:

When the defendant shows up at her home, the complainant doesn't always dare to ask the defendant to leave, because she is afraid that he would become violent.

(Court of Appeal, 64)

A discourse of involuntary consent appears in these cases:

Even though the victim testimony as such is credible, the evaluation of evidence about the number of rapes is difficult because the parties have also had several times intercourse that the victim has not wanted but that she nevertheless has consented to.

(Court of Appeal, 2)

In these cases, the core problem was whether or not a complainant had consented to a sexual act - even if consent is not a definitional element of rape in Finland. Thus, it is unlikely that problems at the level of legal application and evaluation of evidence would be solved solely by adapting consent as part of the definition of rape. Problems often originate from difficulties in distinguishing freely given consent from submission, paralysing fear or a complainant's strategic inaction (Ehrlich, 2001).

In some judgements, the courts have focussed on fear and coercion. In one case, the perpetrator did not use immediate violence to break the complainant's resistance but held the complainant against her will in an apartment for six hours. He threatened her, assaulted her, tried to strangle her and finally raped her. She was so afraid that she was unable to defend herself. The defendant argued that there was a time gap between the violence and the sexual intercourse and that the parties had solved their previous conflict before having sex. When sentencing, the courts evaluated the totality of the defendant's separate crimes in sentencing the punishment (Kouvola Court of Appeal 22.11.2011, no. 1082).

A complainant who, paralysed by fear, submits to intercourse can be held as consenting, albeit against her will. In one judgement, the core problem was how to adjudicate sexual acts that 'the complainant had not wanted, but that she nevertheless had consented [to]'. In such situations, fear and passivity were often a consequence of the perpetrator's previous violence: 
When the defendant shows up to her home, the complainant doesn't always dare to ask the defendant to leave, because she is afraid that he would become violent. The complainant has also told in court that sexual [intercourse has] happened in situations, which, according to the complainant's previous experience, would have resulted in rape, if the complainant wouldn't [voluntarily] agree to sexual intercourse.

(Court of Appeal, 64)

Intimate partner rape, the complainant's incapacity to form or utter her will, and the problem of 'involuntary consent' are all connected to coercive circumstances in violent relationships that have broken the autonomy and trust of the victim. In Appeal Court cases, the autonomy of the victims looks especially weak and fragile if the perpetrator is a family member or otherwise close. In these cases, trust has been destroyed a long time before the rape trial commences. The typical descriptions of facts in legal documents indicate that such victims have great difficulties in setting boundaries, taking care of themselves, and trusting their own experiences and interpretations of events. Many of these victims seem mentally fragile or mentally broken, and they seem to lack selfconfidence and self-respect.

\section{Rape and youth}

Rape cases involving young parties may cause even more trouble to the courts than rapes in intimate partnerships due to problems of autonomy and the circumstances of rape. In cases of child sexual abuse, trust in the relationship between the perpetrator and the victim is a standard factor that the Supreme Court refers to, which indicates that the abuse of trust is an aggravating circumstance (KKO:2018:35; 2018:30; 2017:51; 2017:50; 2017:31; 2011:102). In this part, we analyse cases in which the victim has been above the legal age of consent but nevertheless young: 16-19 years old.

The Supreme Court has provided only a few verdicts in rape cases, and trust was not considered to be a central element in those cases. In district and appeal courts, discourse on trust has circulated in some trials, thus shaping the ways in which knowledge of the events was constructed. Jokila (2010) found that a trust discourse was present in explanations of why a complainant had spent time with the defendant before the alleged crime took place or why she had let him into or gone with him to an apartment. The question of whether a complainant had voluntarily entered or had been forced into an apartment played a central role in the evaluation of evidence in one Supreme Court case (KKO:2004:60).

The courts do not always take an explicit 'no' by a young woman for a 'no'. In one case, the defendant had already come on to her by the time they were going to the apartment of the defendant's sister. They were lying on a bed when the defendant continued his sexual approaches. The defendant's sister testified that the complainant had told the defendant to stop several times; she did not 
intervene, however, because it did not sound like the complainant needed help. After the sexual act, the complainant smoked a cigarette together with the defendant and the sister. They talked about contraception, not about violence. The complainant returned to the apartment, where the defendant came on to her once more. The complainant now pushed him away and hit him in the face. The Court of Appeal (106) dismissed the charge of lower degree rape. The court stated that the complainant's behaviour after the sexual act supported the defendant's version of events.

This case could be interpreted differently. Understood in the context of anxiety and confusion, the girl's behaviour is understandable. She was young. She tried to tell him to stop. Her behaviour afterwards could tell of agony, confusion and breach of trust by the defendant. Afterwards, she hung out for a while with the defendant and the witness, likely to preserve her honour in the eyes of her friends and to try to avoid the stigma of being a rape victim. She may have been ashamed of not having asserted herself against the defendant and not controlling the situation.

Another case, this one between dating teenagers, showed evidence of the complainant having complained and cried after intercourse. According to the reasoning in the verdict of the District Court, the complainant had described how she had tried to persuade the defendant to stop, but she did it in such a way that other people in the house would not be awakened. She had told him that she did not approve of premarital sex and tried to get up from the bed. She had tried to negotiate. She had trusted him and had been confident that he would listen to her and respect her will. Afterwards, she was confused and in shock. The Court of Appeal was not convinced that she had resisted earlier, so the charge of lower grade rape was dismissed (Court of Appeal, 90).

Jokila's study (2010) showed that it is often difficult for courts to understand young women. She found that if the complainant went with the defendant voluntarily to an apartment, tried to tell him to stop (instead of resisting physically and fighting back) and finally stayed in the apartment afterwards, then charges were sometimes dismissed due to lack of evidence (e.g. Court of Appeal, 90 and 106).

Such complainants do not fit in with the idea of the autonomous rational decision-maker who assertively expresses her non-consent and fights against her attacker. But if trust is taken into account in the interpretation of events, then some of these behaviours can be understood. For example, girls are traditionally brought up to behave nicely and to negotiate themselves out of difficult situations. When in the company of someone whom the girl trusts, these tactics should succeed. When confused by the breach of trust, however, the girl might behave, from a judge's perspective, in a strange manner.

In one case (Court of Appeal, 5), rape was committed against a teenage boy. Both the District Court and the Court of Appeal considered the breach of trust to be a relevant element. The boy had met the defendant in a mall. They knew each other, since they were from the same country. Therefore, the boy trusted the defendant and accepted his invitation to his apartment, where the 
defendant gave him alcohol. He then got drunk, lost consciousness and was anally raped.

In Jokila's study (2010), breach of trust was sometimes a relevant factor. One court called rape 'the price for the misplaced trust' (District Court verdict, 53). The lawyers sometimes used the trust discourse to explain why a complainant had spent time with the defendant before the crime. The complainant might explain that she had gone to his place because she trusted him (complainant's statement, 66). In one case, the complainant's lawyer argued with the trust notion and depicted the defendant as someone who had created a feeling of trust between the victim and himself, only to abuse it (written statement, District Court, 56). Further, the court argued for the betrayal of trust over the relevance of mental damage in a case where a disabled girl had trusted the perpetrator (District Court, 88).

\section{Conclusion}

International courts and the Istanbul Convention emphasise that sexual acts should take place with the consent of both parties. This preference for lack of consent over use of force as the central element of rape in criminal law reflects the value of sexual self-determination and autonomy and the protection of the privacy and integrity of the person. In national jurisdictions, the interpretation of use of force in legal definitions has approached the lack-of-consent formulation.

The international tribunals discussed in this chapter have also underlined that cases of sexual intercourse under coercive circumstances should be convicted as rape, even if no immediate violence and force have been used, no direct threats have been given, nor explicit consent has been expressed. Some have argued that coercive circumstances are relevant for situations of war and violent conflict, and that such circumstances would not need to be considered as much during normal states of affairs. Our empirical data suggest otherwise.

In this chapter, we have looked at rape in intimate partnerships and rape among youth. Both the lack-of-consent and the use-of-force constructions focus on the events immediately before and during the rape, whereas in our cases the broader context of coercion was what led to involuntary intercourse. In the cases of intimate partner rape, the victim's autonomy seems to have been restrained to start with; a long history of violence and control formed coercive circumstances in these cases. These victims could not set boundaries, nor did they trust the adequacy of their own experience and interpretation of what had happened between the couple.

The behaviour of the young victims (between the ages of 16 and 19) seemed to be very difficult for the courts to understand. They appeared to have acted illogically. The courts paid attention to how the victim had ended up in the apartment, whether voluntarily or by force - not that the courts reasoned that the specifics of the situation would be part of the elements of 
rape, but that they could be concrete evidentiary facts to rely on. The victims often had not explicitly resisted, and the courts did not value their attempts to negotiate their way out of the situation as evidence. In these cases, the courts reasoned using the trust argument, as they also typically do in cases of child sexual abuse. Thus, trust can be used as a strategy to counter prejudicial assumptions about a complainant's personality and behaviour before, during and after rape.

Trust is essential for autonomy. Trust in human relationships promotes and enables the development of personal autonomy. Trust can also be situational. Our analysis of case law suggests that trust should be analysed in rape cases, in terms of how it is built and how it is broken. Using trust as a central concept, the courts could be more understanding towards young people and could avoid making prejudicial assumptions about a victim's personality and behaviour.

\section{Acknowledgements}

We thank the reviewer and the editors for their valuable comments. This chapter was written as part of research funded by the Academy of Finland, decisions 281788 and 284929.

\section{Notes}

1 Criminal Code, chapter 20, L 563/1998. Available in English at www.finlex.fi/en/laki/ kaannokset/1889/en18890039.pdf.

2 The 1999 law, reforming Chapter 20 of the CC, included a difference between abusing a victim's state of mind (the crime of sexual abuse) and inducing a person into such a state of mind and then committing abuse, which fell under the rape category. In 2011, both actions were placed under the rape category.

3 The 2011 Council of Europe Convention on preventing and combating violence against women and domestic violence, European Treaty Series (ETS) 201. Finland ratified the Convention in 2015.

4 The 1994 Rwandan genocide of the Tutsi minority at the hands of the Hutus included, in addition to the widespread systematic killing of Tutsis, the rampant rape of Tutsi women. Kunarac refers to a case about a group of Muslim women held in sexual enslavement in the city of Foça, Bosnia and Herzegovina, by Serb forces during the Bosnian war of 1992-1995.

5 Such as CEDAW Committee, 7th periodic report of Finland (2014).

6 Susan Ehrlich (2001) found similar interpretations of fear as consent in her Canadian, discourse-analytical study on rape. Ehrlich studied the ways in which legal facts were constructed in two rape cases against young female students, in a university campus.

\section{References}

Adler, Z. (1987). Rape on trial. London: Routledge \& Kegan.

Andersson, U. (2004). Hans (ord) eller hennes: En könsteoretisk analys av straffrättsligt skydd mot sexuella övergrep. [His (word) or Hers? A gender theoretical analysis of criminal legal protection against sexual abuse]. Lund, Sweden: Bokbox.

Asp, P. (2010). Sex och samtycke [Sex and consent]. Uppsala, Sweden: Iustus Förlag. 


\section{Helena Jokila and Johanna Niemi}

Bennet, W., \& Feldman, M. (1984). Reconstructing reality in the courtroom: Justice and judgement in American culture. New Brunswick, NJ: Rutgers University Press.

Berger, P. L., \& Luckmann, T. (1966). The social construction of reality: A treatise in the sociology of knowledge. Harmondsworth, UK: Penguin.

Boyle, C. (1984). Sexual assault. Toronto: Carswell.

Brothers, D. (1982). Trust disturbances among rape and incest victims. $\mathrm{PhD}$ dissertation. New York: Graduate School, Yeshiva University.

Brownmiller, S. (1974; reprinted 1993). Against our will: Men, women, and rape. New York: Fawcett Columbine.

Burgess-Jackson, K. (1996). Rape: A philosophical investigation. Aldershot, UK: Dartmouth.

Burr, V. (1995). An introduction to social constructionism. London: Routledge.

Cole, A. (2010). International criminal law and sexual violence: An overview. In V. Munro \& C. McGlynn (Eds.), Rethinking rape law: International and comparative perspectives (pp. 47-60). London: Routledge.

Davies, M. (2001). Are persons property? Legal debates about property and personality. Aldershot, UK: Ashgate/Dartmouth.

Ehrlich, S. (2001). Representing rape: Language and sexual consent. London: Routledge.

Estrich, S. (1987). Real rape. Cambridge, MA: Harvard University Press.

Fineman, M. A. (2004). The autonomy myth: A theory of dependency. New York: New Press.

Gidycz, C. A., \& Koss, M. P. (1991). The effects of acquaintance rape on the female victim. In A. Parrot \& L. Bechhofer (Eds.), Acquaintance rape: The hidden crime (pp. 270-283). New York: John Wiley \& Sons.

Gotell, L. (2010). Canadian sexual assault law: Neoliberalism and the erosion of feministinspired law reforms. In C. McGlynn \& V. E. Munro (Eds.), Rethinking rape law: International and comparative perspectives (pp. 209-223). New York: Routledge.

Govier, T. (1993). Self-trust, autonomy, and self-esteem. Hypatia, 8(1), 99-120.

Halley, J. (2016). The move to affirmative consent. Signs: Journal of Women in Culture and Society, 42(8), 257-279.

Iceland Review (2018). Parliament votes to change definition of rape. March 25th 2018.

Jokila, H. (2010). Tahdonvastainen suostumus ja liiallisen luottamuksen hinta: Raiskauksen ja muiden seksuaalirikosten oikeudellisen tiedon konstruktiot [Consent against one's will and the price of undue trust]. Helsinki: Suomalainen Lakimiesyhdistys.

Katz, B. (1991). The psychological impact of stranger versus nonstranger rape on victims' recovery. In A. Parrot \& L. Bechhofer (Eds.), Acquaintance rape: The hidden crime (pp. 251-269). New York: John Wiley \& Sons.

Kelman, M. (1981). Interpretive construction in the substantive criminal law. Stanford Law Review, 33(4), 591-673. doi: 10.2307/1228535

Lacey, N. (1998). Unspeakable subjects, impossible rights: Sexuality, integrity and criminal law. Canadian Journal of Law and Jurisprudence, XI(1), 47-68.

Lacey, N., Wells, C., \& Quick, O. (2003). Reconstructing criminal law: Texts and materials (3rd ed.). Cambridge, UK: Cambridge University Press.

Lees, S. (1996). Carnal knowledge: Rape on trial. London: Hamish Hamilton.

Leijonhufvud, M. (2008). Samtyckesutredningen: Lagskydd för den sexuella integriteten. Stockholm: Thomson. 
MacKinnon, C. A. (1996). Rape: On coercion and consent. In D. K. Weisberg (Ed.), Applications of feminist legal theory to women's lives: Sex, violence, work and reproduction (pp. 471-483). Philadelphia: Temple University Press.

MacKinnon, C. A. (2006). Defining rape internationally: A comment on Akayesu. Columbia Journal of Transnational Law, 44(3), 940-958.

MacKinnon, C. A. (2016). Rape redefined. Harvard Law \& Policy Review, 10(2), 431-477.

McGlynn, C., \& Munro, V. E. (Eds.) (2010). Rethinking rape law: International and comparative perspectives. New York: Routledge.

Ministry of Justice (2012) Justitieministeriets publikation. Behoven av att ändra lagstiftningen om våldtäktsbrott (bedömningspromemoria; utredningar och anvisningar 25/ 2012) [The need of rape law reform]. Finland.

Munro, V. (2010). From consent to coercion: Evaluating international and domestic frameworks for the criminalization of rape. In C. McGlynn \& V. E. Munro (Eds.), Rethinking rape law: International and comparative perspectives (pp. 17-29). New York: Routledge.

Naffine, N. (2011). Women and the cast of legal persons. In J. Jones, A. Grear, R. A. Fenton, \& K. Stevenson (Eds.), Gender, sexualities and law (pp. 15-25). Oxford, UK: Routledge.

Näre, S. (2000). Nuorten tyttöjen kohtaama seksuaalinen väkivalta ja loukattu luottamus tunnetaloudessa. In P. Honkatukia, J. Niemi-Kiesiläinen, \& S. Näre (Eds.), Lähentelystä raiskauksiin: Tyttöjen kokemuksia häirinnästä ja seksuaalisesta väkivallasta [The experiences of girls on sexual harassment and violence] (pp. 77-135). Helsinki: Nuorisotutkimusseura.

Nedelsky, J. (1989). Reconceiving autonomy: Sources, thoughts and possibilities. Yale Journal of Law and Feminism, 1(1), 7-36.

Niemi-Kiesiläinen, J., Honkatukia, P., \& Ruuskanen, M. (2007). Legal texts as discourses. In E.-M. Svensson, Å. Gunnarsson, \& M. Davies (Eds.), Exploiting the limits of law (pp. 69-88). Dartmouth, UK: Ashgate.

O'Donovan, K. (1997). With sense, consent, or just a con? Legal subjects in the discourse of autonomy. In N. Naffine \& R. J. Owens (Eds.), Sexing the subject of law (pp. 47-64). London: Routledge.

Pineau, L. (1996). Date rape: A feminist analysis. In D. K. Weisberg (Ed.), Applications of feminist legal theory to women's lives: Sex violence, work, and reproduction (pp. 484494). Philadelphia: Temple University Press.

RP 216/2013 rd. (Finland). Regeringens proposition till riksdagen med förslag till lag om ändring av 20 kap. i strafflagen. [Government proposal for amendments in rape law].

Russell, D. E. H. (1990). Rape in marriage. Expanded and revised edition. Bloomington: Indiana University Press.

Smart, C. (1991). Feminism and the power of law. London: Routledge.

UNDAW. (2010). UN handbook for legislation on violence against women. New York: United Nations Publication.

Walby, S., Olive, P., Towers, J., Francis, B., Strid, S., Krizsan, A. \& Agarwal, B. (2015). Stopping rape: Towards a comprehensive policy. Bristol, UK: Polity Press.

Ylikulju, M. (2017). Raiskauksen toteennäyttäminen rikosprosessissa [Evidence in rape trials]. In J. Niemi, H. Kainulainen, \& P. Honkatukia (Eds.), Sukupuolistunut väkivalta: Oikeudellinen ja sosiaalinen ongelma [Gendered violence: A legal and social problem] (pp. 232-249). Tampere, Finland: Vastapaino. 


\section{Helena Jokila and Johanna Niemi}

\section{Laws and official documents}

Brottsbalk 1962:700 (Criminal Code) Sweden

CC Criminal Code 1889, Finland

CEDAW Committee (2014). Committee on the Elimination of Discrimination against Women. Report on the 7th periodic report of Finland.

Istanbul Convention (2011) The European Convention on preventing and combating violence against women and domestic violence. ETS 210.

\section{Cases}

European Court of Human Rights [ECtHR]

Aydin v Turkey, Sept 25th, 1997 Appl 28293/95, 29494/95 and 30219/96

I. G. v Moldova, May 15th, 2012 Appl 535/07

M. C. v Bulgaria, Dec 4th, 2003 Appl 39272/98

Maslova \& Nalbandov v Russia, Jan 24th, 2008, Appl 839/02

R. C. v UK, Nov 22nd 1995, Appl 20190/92

$X \& Y v$ the Netherlands, March 26th, 1985 Appl 8978/80

International Tribunals

ICTR Akayesu (1998) International Tribunal for Ruanda

ICTY Kunarac (2002) International Tribunal for Former Yugoslavia... 